\title{
Peran Pejabat Pembuat Akta Tanah (PPAT) Dalam Membuat Akta Jual Beli Tanah Menggunakan Cek/Bilyet Giro Sebagai Alat Pembayaran
}

\author{
Slamet Khudhori ${ }^{*}$, Umar Ma'ruf ${ }^{* *}$
}

\author{
* Mahasiswa Program Magister (S2) Kenotariatan Fakultas Hukum UNISSULA, Semarang \\ ** Dosen Fakultas Hukum UNISSULA
}

\begin{abstract}
ABSTRAK
Penelitian tentang "Peran Pejabat Pembuat Akta Tanah (PPAT) Dalam Membuat Akta Jual Beli Tanah Menggunakan Cek/Bilyet Giro Sebagai Alat Pembayaran" bertujuan untuk menganalisis peran PPAT dalam membuat akta jual beli tanah menggunakan cek/bilyet giro sebagai alat pembayaran, hambatan serta cara mengatasinya.

Peran PPAT dalam membuat akta jual beli tanah menggunakan cek/Bilyet Giro sebagai alat pembayaran yaitu mengupayakan proses perjanjian jual beli tanah dapat berjalan lancar dari terjadinya kesepakatan pengikatan jual beli hingga terjadinya serah terima barang berupa tanah melalui serah terima akta pengikatan jual beli. Hal ini mengingat jual beli menggunakan cek/Bilyet Giro sebagai alat pembayaran tidak dilakukan pembayaran pada waktu dilakukannya perjanjian pengikatan jual beli, namun terdapat tenggang waktu pembayaran sesuai dengan masa aktif dan jatuh tempo pembayaran cek/Bilyet Giro.

Hambatan yang dihadapi PPAT dalam membuat akta jual beli tanah menggunakan cek/Bilyet Giro sebagai alat pembayaran yaitu cek/Bilyet Giro sebagai alat pembayaran mempunyai waktu efektif dan jatuh tempo dalam pembayaranya sehingga pembyaran harga tanah tidak dapat dilakukan seketika saat dilakukannya pembuatan akta jual beli. Walaupun kesepakatan mengenai harga dan kondisi tanah yang dijualbelikan telah disepakati yang menandakan jual beli telah terjadi namun penyeraham tanah sebagai benda tidak bergerak melalui penyerahan sertipikat dan akta jual beli tidak dapat segera dilakukan sebelum dilunasinya harga tanah. Untuk mengatasinya dilakukan penempatan sememtara sertipikat dan akta jualbelinya hingga dilunasinya pembayaran harga tanah yang telah disepakati.
\end{abstract}

Kata Kunci : PPAT, Jual Beli, Cek/Bilyet Giro

ABSTRACT

Research on "The Role of Official Deed Officer (PPAT) In Creating a Deed of Sale and Purchase of Land Using Check / Bilyet Giro as Payment Instrument" aims to analyze the role of PPAT in making the deed of buying and selling land using check / bilyet giro as a means of payment, obstacles and how to cope .

The role of PPAT in making the deed of buying and selling land using check / Bilyet Giro as a means of payment is to pursue the process of land purchase agreement can run smoothly from the agreement of binding of sale and purchase until the handover of goods in the form of land through the handover of the deed of buying and selling binding. This is because buying and selling using check / Bilyet Giro as payment instrument is not made at the time of the sale and purchase agreement, but there is a grace period of payment in accordance with the active period and payment due check / Bilyet Giro.

The obstacles faced by PPAT in making the deed of buying and selling of land using check / Bilyet Giro as a means of payment is check / Bilyet Giro as a means of payment has effective time and maturity in payment so that the price of land can not be done instantly when making the deed of sale and purchase. Although the agreement on the price and condition of the land sold has been agreed which indicates the sale and purchase has occurred but the submission of land as immovable property through the delivery of certificate and the deed of sale and purchase can not be done immediately before the settlement of land price. To overcome this done the placement sememtara certificate and the deed of sale until the payment of land payment has been agreed.

Keywords: PPAT, Sale and Purchase, Check / Bilyet Giro

\section{PENDAHULUAN}

Peralihan hak atas tanah merupakan salah satu peristiwa dan/atau perbuatan hukum yang mengakibatkan terjadinya pemindahan hak atas tanah dari pemilik kepada pihak lainnya. Peralihan tersebut bisa disengaja oleh karena adanya perbuatan hukum seperti jual beli, sewa-menyewa dan sebagainya, dan juga tidak disengaja karena adanya peristiwa hukum seperti peralihan hak karena warisan. 
Muhammad Yamin Lubis menyebutkan bila ada kehendak yang disengaja dan disepakati atas sebidang tanah milik, maka didalamnya ada pengalihan hak atas tanah tersebut. Bila pengalihan tersebut dipaksakan oleh kewenangan dan kekuasaan Negara maka disebut dicabut atau mungkin dinasionalisasikan. Dan ini pun harus dengan menempuh persyaratan, sebab terjadi pemutusan hubungan hukum kepemilikan di dalamnya. ${ }^{1}$

Ketentuan tersebut menjelaskan bahwa peralihan hak atas tanah adalah suatu peristiwa/perbuatan hukum yang mengakibatkan berpindahnya hak dari subyek hukum yang satu ke subyek hukum lainnya, sehingga menyebabkan kehilangan kewenangannya terhadap tanah tersebut.

Salah satu cara untuk menguasai atau memiliki hak atas tanah adalah melalui proses jual beli. Pengertian jual beli menurut ketentuan Pasal 1457 Kitab Undang-Undang Hukum Perdata (KUHPerdata) adalah suatu perjanjian dengan mana pihak yang satu berjanji mengikatkan diri untuk menyerahkan suatu benda dan pihak yang lainnya berjanji untuk membayar harga yang telah diperjanjikan. Disamping itu, lembaga hukum jual beli juga diatur dalam hukum adat. Dalam hukum adat, hak milik dapat beralih maupun dialihkan. Jual beli tanah yang mengakibatkan berlihnya hak milik tanah kepada penjual disebut dengan istilah jual lepas.

Jual beli ada dua subjek yaitu penjual dan pembeli, yang masing-masing mempunyai kewajiban dan berbagai hak, maka mereka masing-masing dalam beberapa hal merupakan pihak yang berwajib dan dalam halhal lain merupakan pihak yang berhak. Ini berhubungan dengan sifat timbal balik dari persetujuan jual beli (Werdering overenkomst). ${ }^{2}$

Objek dari jual beli disini adalah hak atas tanah yang akan dijual. Dalam praktek disebut jual beli tanah. Hak atas tanah yang dijual, bukan tanahnya. Memang benar dengan tujuan membeli hak atas tanah ialah supaya pembeli dapat secara sah menguasai dan mempergunakan tanah tersebut, tetapi yang dibeli (dijual) bukan tanahnya, tetapi hak atas tanahnya. ${ }^{3}$

Sistem jual beli tanah dalam hukum adat menganut sistem tunai/konkrit/terang/nyata artinya setiap hubungan harus terlihat nyata. Hal ini karena masyarakat adat masih sangat sederhana, sehingga dalam transaksi jual tanah tersebut baru mengikat apabila transaksi tersebut terlihat secara konkrit dan nyata telah terjadi yaitu dibuktikan dengan adanya pertukaran, berupa penyerahan tanah sebagai objek dengan sekaligus penyerahan uang secara tunai sebagai pembayaran.

"Ketentuan Pasal 37 ayat (1) Peraturan Pemerintah Nomor 24 Tahun 1997 tentang Pendaftaran Tanah, menyebutkan setiap peralihan hak atas tanah melalui jual-beli, hibah, pemasukan modal dalam perusahaan dan perbuatan hukum pemindahan hak lainnya, hanya dapat didaftarkan jika dapat dibuktikan dengan akta yang dibuat Pejabat Pembuat Akte Tanah (PPAT) kecuali lelang. "Dalam UUPA juga menentukan bahwa setiap peralihan, hapusnya dan pembebanannya dengan hak-hak lain harus didaftarkan menurut ketentuan Pasal 19 ayat (1) UUPA yang merupakan pembuktian yang kuat mengenai hapusnya hak milik serta sahnya peralihan dan pembebanan hak konsumen dari masyarakat". ${ }^{4}$

Ketentuan di atas, dapat ditarik suatu pengertian bahwa setiap terjadi peralihan hak atas tanah harus dibuat akta oleh dan di hadapan Pejabat Pembuat Akta Tanah (PPAT). Hal ini dimaksudkan untuk memberikan jaminan perlindungan dan kepastian hukum bagi para pihak. Bila suatu perjanjian jual beli tidak dilakukan di hadapan Pejabat Pembuat Akta Tanah (PPAT) perjanjian jual beli tersebut tetap sah bagi para pihak, namun bila tanpa akta jual beli, tanah tersebut tidak dapat didaftarkan atau dibalik nama ke atas nama pemilik yang baru di kantor pertanahan.

Berdasarkan Pasal 39 ayat (1) Peraturan Pemerintah Nomor 24 Tahun 1997 ditetapkan bahwa Pejabat Pembuat Akta Tanah (PPAT) menolak untuk membuat akta jika :

1. Mengenai bidang tanah yang sudah terdaftar atau hak milik atas rumah susun, kepadanya tidak disampaikan sertifikat asli hak yang bersangkutan atau sertifikat yang diserahkan tidak sesuai dengan daftar-daftar yang ada di Kantor Pertanahan.

2. Mengenai bidang tanah yang belum terdaftar kepadanya tidak disampaikan sebagai berikut :

a. Surat bukti hak sebagaimana dimaksud dalam Pasal 24 ayat (1) atau surat keterangan Kepala Desa/Kelurahan yang menyatakan bahwa tanah yang bersangkutan menguasai bidang tanah tersebut sebagaimana dimaksud dalam Pasal 24 ayat (2)

\footnotetext{
${ }^{1}$ Muhammad Yamin Lubis. 2008. Hukum Pendaftaran Tanah. Mandar Maju. Bandung, h. 27

${ }^{2}$ Idris Zainal. Ketentuan Jual Beli Menurut Hukum Perdata. Fakultas Hukum USU. Medan, h. 36

${ }^{3}$ Effendi Perangin-angin. 1994. Praktek Jual Beli Tanah. Raja Grafindo Persada. Jakarta. h.8

${ }^{4}$ Budi Harsono. 1982. Hukum Agraria Indonesia Sejarah Pembentukan UUPA, Isi dan Pelaksanaannya, Djambatan. Jakarta. h. 117
} 
b. Surat Keterangan yang menyatakan bahwa bidang tanah yang bersangkutan belum bersertifikat dari Kantor Pertanahan atau untuk tanah yang terletak di daerah yang jauh dari Kantor Pertanahan surat keterangan dari pemegang hak yang bersangkutan dengan dikuatkan oleh Kepala Desa/Kelurahan.

Objek tanah dapat berupa tanah yang sudah bersertifikat dan tanah yang belum bersertifikat, misalnya tanah hak milik adat yang belum dimohonkan konversi oleh pemegang haknya menjadi hak milik menurut Pasal 20 ayat (1) UUPA.

Tanah yang belum bersertipikat adalah tanah yang sama sekali belum pernah didaftarkan di Kantor Pertanahan. Tanah tersebut pada umumnya tidak mempunyai alat bukti tertulis selain bahwa tanah tersebut secara nyata (de facto) berada dalam kekuasaan pemilik tana, seperti ada rumah di atasnya atau ditanami dengan tanaman tumbuh (tanah ladang).

Berdasarkan uraian tersebut di atas dapat dikatakan bahwa jual beli terhadap tanah yang belum bersertipikat dapat dilaksanakan di hadapan Pejabat Pembuat Akta Tanah (PPAT) untuk mendapatkan akta jual beli sebagai dasar peralihan hak atas tanah untuk didaftarkan di Kantor Pertanahan jika tanah tersebut akan dibuatkan sertipikatnya.

Jual beli tanah pada umumnya dilakukan dengan pembayaran tunai menggunakan uang tunai. Jual beli tanah dapat pula dilakukan menggunakan alat pembayaran lain yang sah seperti cek/bilyet giro. Namun hal ini jarang dilakukan oleh masyarakat. Cek merupakan surat berharga yang dapat dipergunakan untuk melakukan pembayaran tunai secara giral. Artinya pembayaran tidak dilakukan dengan uang tunai namun menggunakan sebuah surat berharga dengan nilai uang tertentu kepada pihak tertentu. Pembayaran menggunakan cek merupakan pengganti uang chartal.

Pihak-pihak yang terlibat dalam penggunaan cek yaitu penerbit merupakan orang yang menerbitkan atau menarik sejumlah dana dari rekeningnya ke dalam cek; tersangkut yaitu pihak Bank yang memberikan fasilitas cek; pembawa yaitu orang yang ditunjuk untuk mencairkan cek; pemegang yaitu orang yang diberi hak atau yang membawa cek untuk mencairkan cek; pengganti, merupakan orang yang menggantikan pemegang atau kepada endosemen.

Pembayaran cek dilakukan oleh tersangkut atas perintah penerbit atas sejumlah uang tertentu kepada pihak tertentu, yaitu pembawa maupun pemegang cek. Pembayaran cek dapat dilakukan selama cek tidak dibatalkan oleh penerbit. Meskipun cek tersebut dapat dibatalkan namun tetap harus menunggu masa berakhir yaitu setelah 70 hari sejak diterbitkan selama cek tersebut belum diambil atau diuangkan kepada bank oleh pemegang. Selain itu cek mempunyai masa kadaluarsa salama enam bulan lamanya.

Jual beli tanah menggunakan cek berarti pembayaran atas harga tanah dibayar menggunakan cek. Pembayarana dengan cek pada umumnya tidak langsung dapat dicarikan dananya, tergantung dari ketersedian dana dari penerbit. Hal ini menyebabkan pembayaran harga tanah tergantung dari ketersediaan dana dari penerbit cek. Hal ini menyebabkan waktu pembayaran harga tanah juga tergantung dari ketersediaan dana pada cek. Selain itu pembayaran dengan cek tergantung pula dengan waktu jatuh tempo cek. Pada perjanjian jual beli tanah menggunakan cek sebagai alat pembayaran antara penjual dan pembeli dapat menimbulkan masalah mengenai waktu pembayarannya maupun ketersediaan dana dalam cek. Masalah tersebut seperti kapan penjual menyerahkan sertipikat tanah, apakah saat pembeli menyerahkan cek atau saat penjual mencairkan cek dan dana sudah diterimanya.

Masalah tersebut berlanjut pada saat penandatanganan akta jual beli tanah, yaitu kapan ditandanganinya akta jual beli. Apakah akta jual beli tanah ditandatangani setelah atau sebelum pembayaran tanah dilunasi sementara pembayaran menggunakan cek/bilyet giro pada umumnya tidak dilakukan seketika namun terdapat jangka waktu, misalnya menunggu ketersediaan dana dari penerbit.

Fenomena yang terjadi di Kabupaten Pekalongan jual beli tanah menggunakan cek/bilyet giro jarang dilakukan. Namun ada masyarakat yang melakukan jual beli tanah menggunakan cek/bilyet giro. Jual beli tanah menggunakan cek/bilyet giro ada yang dilakukan di hadapan Pejabat Pembuat Akta Tanah (PPAT) saat terjadinya transaksi jual beli dan ada juga yang dilakukan di bawah tangan. Pada jual beli tanah yang dilakukan di bawah tangan pembuatan akta jual beli diserahkan kepada pembeli kapan akan dilakukan pembuatan akta jual beli tanah tersebut beserta pendaftaran peralihan hak atas tanah pada kantor pertanahan.

Transaksi jual beli tanah menggunakan cek/bilyet giro di Kabupaten Pekalongan pada umumnya dilakukan oleh para pihak yaitu penjual dan pembeli yang sudah saling kenal. Hal ini menyangkut masalah kepercayaan antara para pihak karena pembayaran dengan cek/bilyet giro bukan merupakan transaksi jual beli secara kontan atau tunai namun ada jangka waktu tertentu untuk menyelesaikan pembayaran.

Pada transaksi jual beli tanah tanah menggunakan cek/bilyet giro di hadapan Pejabat Pembuat Akta Tanah (PPAT) pembayaran dilakukan di hadapan Pejabat Pembuat Akta Tanah (PPAT) selanjutnya penandatanganan 
akta jual beli dilakukan setelah penjual mencairkan cek/bilyet giro yang diterimanya. Untuk mengantisipasi hal-hal yang tidak diinginkan seperti adanya cek/bilyet giro kosong sertipikat tanah objek jual beli disimpan di Pejabat Pembuat Akta Tanah (PPAT). Proses selanjutnya dilakukan setelah pembayaran jual beli tanah selesai.

Jual beli tanah menggunakan cek/bilyet giro sebagai alat pembayaran lebih rumit karena tidak tuntas seperti jual beli menggunakan uang cash. Hal inilah peran notaris sebagai Pejabat Pembuat Akta Tanah (PPAT) dibutuhkan untuk merumuskan bagaimana perjanjian jual beli tanah menggunakan cek/bilyet giro sebagai alat pembayaran. Perumusan akta jual beli tanah yang tepat diperlukan agar tidak menimbulkan masalah dikemudian hari.

Perkembangan sekarang transaksi perbankan dilakukan secara elektronik, termasuk pemindahbukuan dana cek/bilyet giro. Pemindahbukuan cek/bilyet giro dilakukan oleh petugas bank. Pemindahbukuan dana cek/bilyet giro oleh petugas bank melalui sarana elektronik dapat dikategorikan sebagai transaksi elektronik. Menurut Pasal 1 ke 2 Undang-Undang Nomor 11 Tahun 2008 tentang Informasi dan Transaksi Elektronik bahwa transaksi Elektronik adalah perbuatan hukum yang dilakukan dengan menggunakan komputer, jaringan komputer, dan/atau media elektronik lainnya.

Permasalahan penelitian ini yaitu bagaimana peran Pejabat Pembuat Akta Tanah (PPAT) dalam membuat akta jual beli tanah menggunakan cek/bilyet giro sebagai alat pembayaran dan hambatan apa yang dihadapi Pejabat Pembuat Akta Tanah (PPAT) dalam membuat akta jual beli tanah menggunakan cek/bilyet giro sebagai alat pembayaran dan cara mengatasi hambatan tersebut.

\section{Metode Penelitian}

Penelitian ini menggunakan pendekatan yuridis sosiologis, yaitu pendekatan terhadap kajian hukum dan masyarakat. Pendekatan sosiologi membahas praktik penerapan peraturan perundan-undangan dalam kehidupan sosial masyarakat.

Sumber dan jenis data yang digunakan pada penelitian ini berupa data primer yaitu hasil wawancara tentang peran notaris dalam pembuatan akta jual beli tanah menggunakan cek/bilyet giro sebagai alat pembayaran dan data sekunder berupa dokumen-dokumen resmi, buku-buku, hasil-hasil penelitian yang berwujud laporan, dan buku harian. Pengumpulan data dilakukan dengan wawancara, studi dokumen dan studi lapangan.

Pada penelitian ini data yang diperoleh akan dianalisis secara kualitatif, yaitu metode yang menghasilkan analisis data berdasarkan apa yang dinyatakan oleh responden secara tertulis / lesan. Data hasil analisis tersebut kemudian akan digunakan untuk menarik kesimpulan dengan metode berpikir deduktif. "Deduktif ialah cara berfikir yang bersandarkan pada yang umum, dan dari yang umum itu menetapkan yang khusus itu". ${ }^{5}$

\section{HASIL PENELITIAN DAN PEMBAHASAN}

Pada parktiknya jual beli tanah kadang menggunakan cek/Bilyet Giro sebagai alat pembayaran. Pembuatan akta jual beli tanah menggunakan cek/Bilyet Giro sebagai alat pembayaran pada dasarnya sama dengan pembuatan akta jual beli tanah menggunakan uang tunai atau secara cash. Berkaitan dengan hal tersebut maka klausula atau petitum dalam akta jual beli menggunakan cek/Bilyet Giru sebagai alat pembayaran tidak berbeda jauh dengan petitum akta jual beli tanah menggunakan uang tunai sebagai alat pembayaran seperti isi Perjanjian Pengikatan Jual Beli Tanah sebagaimana diuraikan di atas.

Perbedaan akta pengikatan jual beli tanah menggunakan uang tunai dan akta pengikatan jual beli tanah menggunakan sek/Bilyet Giro terletak pada pelaksanaan pembayarannya. Pada perjanjian jual beli menggunakan uang tunai pembayarannya dapat dilakukan seketika secara keseluruhan dan atau dengan tempo waktu tertentu baik sebagian atau seluruhnya. Pada perjanjian pengikatan jual beli tanah menggunakan cek/Bilyet Giro sebagai alat pembayaran maka pembayarannya tunduk pada ketentuan proses pembayaran cek/Bilyet Giro. Pembayaran menggunakan cek/Bilyet Giro dilakukan melalui pihak bank.

Penjual dan pembeli dapat secara bersama-sama datang ke bank untuk mencairkan cek/Bilyet Giro atau pihak pembeli memberikan cek/Bilyet Giro kepada pihak penjual untuk dicairkan pada bank sesuai dengan waktu yang telah ditentukan dalam cek/Bilyet Giro tersebut. Dalam hal ini pihak pembeli harus memiliki dana yang cukup dalam rekening giro yang bersangkutan sesuai dengan harga tanah yang diperjanjikan.

Klausula akta pengikatan jual beli tanah menggunakan cek/Bilyet Giro sebagai pembayaran berbeda dengan klausula akta pengikatan jual beli tanah menggunakan uang tunai sebagai alat pembayaran. Perbedaan mendasar klausula akta pengikatan jual beli tanah menggunakan cek/Bilyet Giro sebagai alat pembayaran

\footnotetext{
${ }^{5}$ Ibid, h. 21.
} 
dengan klausula akta pengikatan jual beli tanah menggunakan uang tunai sebagai alat pembayaran terletak pada klausula yang mengatur tentang alat dan teknis pembayaran tanah.

Berdasarkan klausula-klausula perjanjian pengikatan jual beli menggunakan cek/Bilyet Giro maka dapat diketahui bahwa sebelum dibayar lunas tanah yang diperjual belikan maka sertipikat tanah berada di notaris di mana akta pengikatan jual beli tanah di buat. Hal ini untuk menjaga berbagai kemungkinan apabila cek/Bilyet Giro tidak ada dananya sehingga harga tanah yang telah disepakati tidak terbayar lunas.

Penenmpatan sertipikat pada notaris untuk menjaga berbagai kemungkinan yang terjadi sebelum transaksi jual beli selesai, dalam arti harga tanah dibayar lunas. Berbagai kemungkinan tersebut misalnya pembeli tidak melunasi harga tanah yang disepakati karena cek/Bilyet Giro tidak ada dananya dan atau itikad tidak baik dari penjual maupun pembeli.

Dari sisi penjual dapat dihindari tidak diserahkannya sertipikat setelah cek/Bilyet Giro diuangkan di bank karena pencairan cek/Bilyet Giro dapat dilakukan sendiri oleh pihak yang membawa cek/Bilyet Giro tampa sepengetahuan penjual. Dari sisi pembeli dapat dihindari terjadinya penipuan menggunakan cek/Bilyet Giro. Pada intinya penempatan sertipikat pada Pejabat Pembuat Akta Tanah (PPAT) untuk menjamin dilaksanakannya hak dan kewajiban penjual dan pembeli

Hambatan yang dihadapi Pejabat Pembuat Akta Tanah (PPAT) dalam membuat akta pengikatan jual beli tanah menggunakan Cek/Bilyet Giro sebagai alat pembayaran yaitu transaksi menggunakan cek/Bilyet Giro tidak sama dengan transaksi menggunakan uang tunai. Pada transaksi jual beli tanah menggunakan uang tunai, proses transaksi bisa langsung selesai. Demikian pula dalam pembuatan akta jual beli tanah bisa dilaksanakan dalam satu hari. Artinya transaksi dan terjadinya serah terima dapat dilakukan sekali waktu tuntas tanpa ada tenggang waktu. Berbeda dengan jual beli tanah menggunakan cek/Bilyet Giro, tidak dapat dilakukan secara tuntas dalam satu waktu. Hal ini mengingat cek/Bilyet Giro sebagai alat pembyaran mermpunyai aturan-aturan tertentu, seperti adanya tanggal efektif dan tanggal jatuh tempo, serta waktu efektif Bilyet Giro yaitu 70 hari. Hal ini sebagaimana ditentukan dalam Pasal 10 ayat (1) Peraturan Bank Indonesia Nomor 18/41/Pbi/2016 Tentang Bilyet Giro yang menyatakan bahwa Tenggang Waktu Pengunjukan Bilyet Giro yaitu 70 (tujuh puluh) hari terhitung sejak Tanggal Penarikan

Jual beli tanah menggunakan cek/Bilyet Giro terkendala pada proses pembyarannya yang berakibat pada penyerahan sertipikat tanah objek jual beli.pada praktiknya jika pembayaran harga tanah belum dilaksanakan secara tunai maka sertipikat belum bisa diserahkan kepada pihak pembeli. Namun demikian tentunya pembeli tidak mau menyerahkan cek/Bilyet Giro sebelum sertipikat tanah diserahkan kepadanya.

Jual beli hak milik atas tanah adalah perbuatan hukum untuk memindahkan hak atas tanah kepada pihak lain. Pemindahan hak dilakukan apabila status hukum pihak yang akan menguasai tanah tersebut memenuhi persyaratan sebagai pemegang hak atas tanah tersebut bersedia untuk memindahkan haknya. Dalam hal ini, penjual dan pembeli datang ke kantor Pejabat Pembuat Akta Tanah (PPAT) untuk membuat akta mengenai tanah yang dijual. Dengan dibuatnya akta jual beli tanah oleh Pejabat Pembuat Akta Tanah (PPAT) maka pada saat itu juga hak beralih dari penjual kepada pembeli dan tanpa akta Pejabat Pembuat Akta Tanah (PPAT) jual beli tersebut tidak dapat didaftarkan ke Kantor Pertanahan dengan memenuhi syarat-syarat yang dibutuhkan, seperti pembayaran lunas atas tanah yang dibeli dan apakah harga tanah sesuai dengan akta yang telah diserahkan oleh pembeli kepada penjual, dan apakah penjual telah menerima harga tanah tersebut dari pembeli. Pertanyaan tersebut perlu ditanyakan karena dalam akta ditulis bahwa uang pembelian sudah dibayar lunas dan diterima oleh penjual, sehingga akta itu juga berlaku sebagai tanda terima yang sah. ${ }^{6}$

Mengenai pembayaran dalam jual beli tanah ini dalam prakteknya akan dilakukan dalam dua tahap yang berbeda. Pertama, pembayaran telah dimulai sebelum jual beli dilakukan di hadapan Pejabat Pembuat Akta Tanah (PPAT), sedangkan yang kedua pembayaran baru dimulai setelah penandatanganan perjanjian jual beli. Namun demikian, ada juga yang telah dibayar lunas sebelum penandatanganan perjanjian jual beli, bahkan ada pula yang membayar tersebut harus dibuatkan kwitansi/tanda terima. Oleh karena itu, kwitansi pembayaran yang dimaksudkan ini sengaja dibuat untuk dijadikan suatu bukti bahwa telah terjadi penerimaan sejumlah uang sesuai dengan yang tertera pada kwitansi tersebut. Oleh karena itu, kwitansi yang ditandatangani hanya berlaku antara pihak pembayar dan penerima saja. ${ }^{7}$ Setelah menerima dan memeriksa surat-surat yang diperlukan, maka

\footnotetext{
6 Sunardi, 2016, Kedudukan Kuasa Menjual Atas Dasar Surat Keterangan Notaris Tentang Pembayaran Lunas dalam Pembuatan Akta Jual Beli Balik Nama, Jurnal Ilmiah Prodi Magister Kenotariatan, Universitas Udayana, h. 8

7 Harun Al Kashid, 1987, Sekilas Tentang Jual Beli Tanah (Berikut Peraturan Peraturanperaturannya), Ghalia Indonesia, Jakarta, h. .62
} 
Notaris/Pejabat Pembuat Akta Tanah (PPAT) akan membuat akta jual beli tanah yang ditandatangani oleh para pihak atau kuasanya, dua orang saksi dan Notaris/Pejabat Pembuat Akta Tanah (PPAT) itu sendiri. ${ }^{8}$

Pembayaran dalam jual beli tanah yang demikian itu tidak menjadi masalah manakala dilakukan secara tunai. Pada tahap pembayaran kedua atau pelunasan dapat dilakukan proses jual beli beserta penyerahan barang berupa tanah melalui penyerahan sertipikat dan akta jual belinya. Berebda dengan jual beli tanah menggunakan cek/Bilyet Giro pelaksanaan serah terima barang tidak dapat segera dilakukan karena penjual yang menerima cek/Bilyet Giro tidak harus melakukan penarikan / pemindahbukuan cek/Bilyet Giro yang bersangkutan, disamping itu sebelum bilyet giro masuk masa aktif belum dapat dilakukan transaksi. Artinya ada jeda waktu dalam proses jual beli tanah menggunakan cek/Bilyet Giro sebagai alat pembayaran yang berpengaruh dalam pembuatan akta jual beli.

Untuk mengatasi hambatan yang dihadapi Pejabat Pembuat Akta Tanah (PPAT) dalam membuat akta pengikatan jual beli tanah menggunakan Cek/Bilyet Giro sebagai alat pembayaran berupa hambatan masalah penyerahan sertipikat tanah dan akta jual belinya yang disebabkan pembayaran harga tanah menggunakan cek/Bilyet Giro terdapat tenggang waktu sesuai dengan tanggal efektifnya yaitu dengan menempatkan sertipikat tanah pada Pejabat Pembuat Akta Tanah (PPAT). Walapun kesepakatan mengenai harga dan kondisi tanah yang dijualbelikan telah disepakati yang menandakan jual beli telah terjadi namun penyeraham tanah sebagai benda tidak bergerak melalui penyerahan sertipikat dan akta jual beli tidak dapat segera dilakukan sebelum dilunasinya harga tanah.

Menurut Salim perjanjian jual beli adalah Suatu Perjanjian yang dibuat antara pihak penjual dan pihak pembeli. ${ }^{9}$ Di dalam perjanjian itu pihak penjual berkewajiban untuk menyerahkan objek jual beli kepada pembeli dan berhak menerima harga dan pembeli berkewajiban untuk membayar harga dan berhak menerima objek tersebut. ${ }^{10}$ Unsur yang terkandung dalam defenisi tersebut adalah adanya subjek hukum, yaitu penjual dan pembeli, adanya kesepakatan antara penjual dan pembeli tentang barang dan harga, adanya hak dan kewajiban yang timbul antara pihak penjual dan pembeli

Pada jual beli menggunakan cek/Bilyet Giro sebagai alat pembayaran maka hak dan kewajiban yang timbul dalam perjanjian jual beli tanah antara pihak penjual dan pembeli, khususnya mengenai penyerahan sertipikat dan akta jual beli belum dapat dilaksanakan sepanjang belum dilunasinya harga tanah yang disepakati.

Unsur pokok dalam perjanjian jual beli adalah barang dan harga, dimana antara penjual dan pembeli harus ada kata sepakat tentang harga dan benda yang menjadi objek jual beli. Suatu perjanjian jual beli yang sah lahir apabila kedua belah pihak telah setuju tentang harga dan barang. Sifat konsensual dari perjanjian jual beli tersebut ditegaskan dalam pasal 1458 yang berbunyi " jual beli dianggap sudah terjadi antara kedua belah pihak seketika setelah mereka mencapai kata sepakat tentang barang dan harga, meskipun barang ini belum diserahkan maupun harganya belum dibayar ". ${ }^{11}$

Jadi dalam perjanjian jual beli tanah menggunakan cek/Bilyet Giro sebagai alat pembayaran, jual beli sudah terjadi setelah disepakatinya barang berupa tanah beserta harganya. Meskipum harga tanah belum dibayar mengingat pembayaran melalui cek/Bilyet Giro umumnya tidak dapat dilakukan seketika. Namun harus mengikuti tanggal efektif dan jatuh tempo cek/Bilyet Giro tersebut.

Apabila terjadi kesepakatan mengenai harga dan barang namun ada hal lain yang tidak disepakati yang terkait dengan perjanjian jual beli tersebut, jual beli tetap tidak terjadi karena tidak terjadi kesepakatan. Akan tetapi, jika para pihak telah menyepakati unsur esensial dari perjanjian jual beli tersebut, dan para pihak tidak mempersoalkan hal lainnya, klausul-klausul yang dianggap berlaku dalam perjanjian tersebut merupakan ketentuan-ketentuan tentang jual beli yang ada dalam perundang-undangan (BW) atau biasa disebut unsur naturalia. ${ }^{12}$ Walaupun telah terjadi persesuaian antara kehendak dan pernyataan, namun belum tentu barang itu menjadi milik pembeli, karena harus diikuti proses penyerahan (levering) benda yang tergantung kepada jenis bendanya yaitu: ${ }^{13} 1$. Benda Bergerak Penyerahan benda bergerak dilakukan dengan penyerahan nyata dan kunci atas benda tersebut. 2. Piutang atas nama dan benda tak bertubuh Penyerahan akan piutang atas nama dan benda tak bertubuh lainnya dilakukan dengan sebuah akta otentik atau akta di bawah tangan. 3. Benda tidak

\footnotetext{
${ }^{8}$ Sunardi, op. Cit., h. 8

${ }^{9}$ Salim H.S., 2003, Hukum Kontrak Teori dan Teknik Penyusunan Kontrak, Sinar Grafika, Jakarta, h. 49.

${ }^{10}$ Ibid.

${ }^{11}$ R.Subekti, 1995, Aneka Perjanjian, Bandung, Citra Aditya Bakti, Bandung, h. 2

${ }^{12}$ Ahmadi Miru, 2007, Hukum Kontrak dan Perancangan Kontrak, Raja Grafindo Persada, Jakarta, h. 127

${ }^{13}$ Ibid., h. 9.
} 
bergerak Untuk benda tidak bergerak, penyerahannya dilakukan dengan pengumuman akan akta yang bersangkutan, di Kantor Penyimpan Hipotek.

Demikian pula dalam perjanjian jual beli tanah menggunakan cek/Bilyet Giro sebagai alat pembayaran kesepakatan mengenai penyerahan sertipikat selalu menjadi obyek masalah. Waktu penyerahan sertipikat dan akta jual belinya merupakan masalah yang selalu muncul. Hal ini mengingat harga tanah belum dilunasi karena pembayaran dengan cek/Bilyet Giro tunduk pada aturan-aturan cek/Bilyet Giro sebagai alat pembayaran, khususnya adanya tanggal efektif dan jatuh tempo cek/Bilyet Giro dimaksud.

Penempatan dan atau penyimpan sertipikat dan akta jual belinya pada Pejabat Pembuat Akta Tanah (PPAT) pada dasarnya untuk menjaga terjadinya hal-hal yang tidak diinginkan berkaitan dengan cek/Bilyet Giro seperti adanya cek/Bilyet Giro kosong atau tidak ada dananya padahal sertipikat sudah diserahkan kepada pembeli.

Penempatan dan atau penyimpanan sementara sertipikat dan akta jual belinya hingga dilunasinya harga yang telah disepakati bukanlah hal yang mutlak. Pejabat Pembuat Akta Tanah (PPAT) dapat menyerahkan sepenuhnya kepada para pihak apakah akan disimpan dan ditempatkan sementara pada Pejabat Pembuat Akta Tanah (PPAT) atau tidak. hal ini disebabkan bahwa perjanjian berlaku asas kebebasan berkontrak.

Asas kebebasan berkontrak arrtinya setiap orang bebas membuat perjanjian yang terdapat dalam undangundang yang dikenal sebagai perjanjian bernama : jual beli, sewa menyewa, tukar menukar. Asas kebebasan berkontrak ini dapat disimpulkan dari Pasal 1338 ayat $1 \mathrm{KUH}$ Perdata yang menentukan : "semua perjanjian yang dibuat secara sah berlaku sebagai Undang-Undang bagi mereka yang membuatnya". ${ }^{14}$ Penempatan dan atau penyimpanan semnentara sertipikat dan akta jual belinya hingga dilunasinya harga tanah yang telah disepakati merupakan salah satu upaya Pejabat Pembuat Akta Tanah (PPAT) dalam melaksanakan tanggungjawabnya sebagai pejabat pembuat akta otentik.

Penempatan dan atau penhyimpanan sementara sertipikat dalam jual beli tanah menggunakan cek/Bilyet Giro sebagai alat pembayaran merupakan upaya agar akta juali tanah yang dibuat Pejabat Pembuat Akta Tanah (PPAT) sesuai peraturan perundang-undangan, peraturan mengenai diserahkannya barang dalam jual-beli. Upaya ini juga dilakukan untuk menghindari terjadinua kerugian salah satu pihak dalam perjanjian jual beli tersebut. Terlaksananya perjanjian jual beli tanah menggunakan cek/Bilyet Giro sebagai alat pembayaran sehingga tidak timbul sengketa menunjukkan Pejabat Pembuat Akta Tanah (PPAT) telah melaksanakan tanggungjawabnya.

\section{PENUTUP}

\section{Simpulan}

Peran PPAT dalam membuat akta jual beli tanah menggunakan cek/Bilyet Giro sebagai alat pembayaran yaitu mengupayakan proses perjanjian jual beli tanah dapat berjalan lancar dari terjadinya kesepakatan pengikatan jual beli hingga terjadinya serah terima barang berupa tanah melalui serah terima akta pengikatan jual beli. Hal ini mengingat jual beli menggunakan cek/Bilyet Giro sebagai alat pembayaran tidak dilakukan pembayaran pada waktu dilakukannya perjanjian pengikatan jual beli, namun terdapat tenggang waktu pembayaran sesuai dengan masa aktif dan jatuh tempo pembayaran cek/Bilyet Giro.

Hambatan yang dihadapi PPAT dalam membuat akta jual beli tanah menggunakan cek/Bilyet Giro sebagai alat pembayaran yaitu cek/Bilyet Giro sebagai alat pembayaran mempunyai waktu efektif dan jatuh tempo dalam pembayaranya sehingga pembyaran harga tanah tidak dapat dilakukan seketika saat dilakukannya pembuatan akta jual beli. Walaupun kesepakatan mengenai harga dan kondisi tanah yang dijualbelikan telah disepakati yang menandakan jual beli telah terjadi namun penyeraham tanah sebagai benda tidak bergerak melalui penyerahan sertipikat dan akta jual beli tidak dapat segera dilakukan sebelum dilunasinya harga tanah. Untuk mengatasinya dilakukan penempatan sememtara sertipikat dan akta jualbelinya hingga dilunasinya pembayaran harga tanah yang telah disepakati.

\section{Saran}

Sebagai bentuk dan tanggung jawab Pejabat Pembuat Akta Tanah (PPAT) dalam pembuatan akta pengikatan jual beli menggunakan cek/Bilyet Giro sebagai alat pembayaran hendaknya dilakukan penempatan dan penyimpanan sertipikat serta akta jual beli pada kantor Pejabat Pembuat Akta Tanah (PPAT) hingga dilunasinya pembayaran harga yang telah disepakati untuk menghindari hal-hal yang tidak diinginkan seperti tidak dilunasinya harga atau adanya itikad tidak baik dari masing-masing pihak. Pihak pembeli hendaknya

\footnotetext{
${ }^{14}$ Komariyah, 2002, Hukum Perdata, Universitas Muhammadiyah Malang, Malang, , h.. 179-181.
} 
mempesiapkan dana dalam cek/Bilyet Giro dalam jumlah cukup agar transaksi jual beli tanah dengan cek/Bilyet Giro sebagai alat pembayaran berjalan lancar.

\section{DAFTAR PUSTAKA}

Muhammad Yamin Lubis. 2008. Hukum Pendaftaran Tanah. Mandar Maju. Bandung

Idris Zainal. Ketentuan Jual Beli Menurut Hukum Perdata. Fakultas Hukum USU. Medan

Effendi Perangin-angin. 1994. Praktek Jual Beli Tanah. Raja Grafindo Persada. Jakarta.

Budi Harsono. 1982. Hukum Agraria Indonesia Sejarah Pembentukan UUPA, Isi dan Pelaksanaannya, Djambatan. Jakarta.

Sunardi, 2016, Kedudukan Kuasa Menjual Atas Dasar Surat Keterangan Notaris Tentang Pembayaran Lunas dalam Pembuatan Akta Jual Beli Balik Nama, Jurnal IImiah Prodi Magister Kenotariatan, Universitas Udayana.

Harun Al Kashid, 1987, Sekilas Tentang Jual Beli Tanah (Berikut Peraturan Peraturanperaturannya), Ghalia Indonesia, Jakarta.

Salim H.S., 2003, Hukum Kontrak Teori dan Teknik Penyusunan Kontrak, Sinar Grafika, Jakarta

R.Subekti, 1995, Aneka Perjanjian, Bandung, Citra Aditya Bakti, Bandung.

Ahmadi Miru, 2007, Hukum Kontrak dan Perancangan Kontrak, Raja Grafindo Persada, Jakarta

Komariyah, 2002, Hukum Perdata, Universitas Muhammadiyah Malang, Malang 